\title{
Transition from endogenous to exogenous nutrition: larval size parameters determining the start of external feeding and size of prey ingested by Ruegen spring herring Clupea harengus
}

\author{
A. Busch \\ Rostock University, Department of Biology, Möllner Str. 13, D-18109 Rostock-Lichtenhagen, Germany
}

\begin{abstract}
ABSTRAC.T: Larvae of Ruegen spring herring Clupea harengus L. were reared from naturally fertilized eggs in 1990, 1991, and 1992, in order to examine which larval size parameters (length, mouth width, mouth opening and oesophagus diameter) correlated with the time of the external feeding start and the size of prey ingested. The experimental conditions were similar to those occurring naturally at this time (at Greifswalder Bodden, Germany). First feeding took place during or at the end of the period when the oesophagus had significantly opened. The increase of the oesophagus diameter was related to the decrease of the yolk sac diameter, rather than to the increase in standard length. ln addition to physiological causes, these results imply that the increase of the oesophagus diameter has mechanical causes, such as the decrease of yolk sac pressure on the oesophagus as yolk is resorbed. A mean decrease of $2.0 \pm 0.6 \mu \mathrm{m}$ in yolk sac diameter implies a $1.0 \mu \mathrm{m}$ increase in oesophagus diameter. At the first feeding time point and later, the ratio between the oesophagus diameter and the width of eaten prey was closer to $1: 1$ than the corresponding ratios for mouth sizes. Whereas the ratio of the oesophagus diameter and the width of the eaten prey was between 0.5 and 1.4 , it varied between 1.4 and 7.4 for the corresponding mouth size parameters and the prey width. The results of this investigation show that external feeding starts when the yolk is exhausted sufficiently to allow the oesophagus to open so that prey organisms can pass through it. Thus, external feedung can be prevented, especially for young larvae, not only by prey limitation, but also by a restriction of the oesophagus opening - even if sufficient prey is available.
\end{abstract}

KEY WORDS: Herring larvae · First feeding Oesophagus opening

\section{INTRODUCTION}

The transition from yolk sac to actively feeding larvae is considered to be the most critical event during the early life of larval fishes (Hjort 1914). Hjort's concept maintains that herring larval survival and hence recruitment of the fish stock are primarily determined by food limitation in this period. This hypothesis has been modified and developed by a number of workers: e.g. Cushing's (1975) 'match-mismatch hypothesis'; Lasker's $(1975,1978)$ 'vertical stability hypothesis'; Fraser's (1970) and Fortier \& Harris' (1989) 'resource use competition hypothesis'; Ware's (1975) and Shepherd \& Cushing's (1980) 'growth-mor- tality hypothesis'. In addition to the existence of sufficient food of the correct size and species composition, survival of a minimum number of larvae for maintenance of the population demands the ability and readiness of larvae to use external food when the yolk is exhausted. Earlier and recent studies show that the attainment of a certain minimum size, e.g. length and mouth width, is the prerequisite for an effective swimming and prey catching mode (Rosenthal \& Hempel 1970, Beyer 1980, Cohen \& Lough 1983, Uotani 1985, Grosse \& Hay 1988, Heath 1989, Economou 1991, Munk 1992, Crockford \& Johnston 1993, Bremigan \& Stein 1994 and others). In addition, the nervous system, sense organs, gill apparatus and digestive tract 
must also be sufficiently developed to allow feeding (Blaxter 1965, 1968, 1969, Rosenthal 1969, Dabrowski 1984, Kiørboe et al. 1985, Gibson \& Ezzi 1992, Collins \& Nelson 1993, Johnston 1993).

However, even if these larval features and abilities are developed, external feeding does not necessarily take place, despite the presence of sufficient food (Busch 1993). This could be due to larval condition and activity (see Blaxter \& Hunter 1982, Batty 1987). However, other rarely investigated parameters could be responsible for the absence of feeding activities, e.g. the restriction of food intake by the oesophagus diameter.

This study demonstrates for the first time for herring larvae Clupea harengus L. that external feeding depends primarily on the oesophagus diameter and on the prey width, and secondarily on other parameters such as length, mouth size and gut development. It is further shown that the increase of the oesophagus opening, and therefore the start of external feeding, is related to yolk use.

\section{MATERIAL AND METHODS}

Larval rearing and handling. The investigations were performed between February and June 1990 to 1992, at the Gager field station on the Greifswalder Bodden, Germany (Fig. 1). Naturally fertilized eggs were used to ensure that larvae came from a large amount of females and males ispawning shoal of ca 10000 fish, which had a total length of between 24 to $30 \mathrm{~cm}$ ), and incorporated a wide range of the genetic material of the stock (see Aneer et al. 1983). Spawn was collected by divers $5 \mathrm{~d}$ before the hatching of the larvae, and was transferred to 55 I aquarium tanks. The tanks were fitted with an internal filter (Flüchter 1964) with a turnover rate for 1 tank of 79 min. After hatching, larvae were subsequently placed in $140 \mathrm{l}$ circular black tanks. The tanks were aerated indirectly via an external filter (turnover rate was 1 tank in $1.4 \mathrm{~d}$ ). The stocking density was 6 to 14 larvae ${ }^{-1}$. The rearing conditions for each cohort of larvae (Table 1) were similar to sea conditions at this time. The difference between the maintenance temperature and the temperature in the sea was $0.5 \pm 1.5^{\circ} \mathrm{C}$ and not significant ( $n=18, \alpha=5 \%$ ). The salinity in the tanks was identical to that in the sea, since water was replaced daily. Salinity fluctuations were small (Table 1). The oxygen saturation fluctuated somewhat, but was generally in the range of 60 to $100 \%$. Light was supplied by white fluorescent tubes equipped with a diffuser and situated $0.6 \mathrm{~m}$ above the tanks (intensity: $1400 \mathrm{Ix}$ ). The lighting regime was $12 \mathrm{~h}$ light: $12 \mathrm{~h}$ dark, with $30 \mathrm{~min}$ of dim light (600 to $800 \mathrm{~lx}$ ) at the beginning (08:00 h) and end
(19:30 h) of each light period. Zooplankton filtered from seawater were added to the tanks. Zooplankton density was monitored daily. Thus, density never

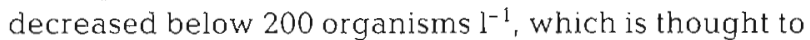
be high enough for successful feeding (see Schnack 1972, Werner \& Blaxter 1980, Pedersen et al. 1987). The width of the offered prey (Table 2) ranged from $0.062 \mathrm{~mm}$ (e.g. Acartia bifilosa naupliar stage $1=\mathrm{N} 1$ ) to $0.234 \mathrm{~mm}$ (e.g. A. bifilosa copepodite stage $6=\mathrm{C} 6$ ). All developmental stages of the prey were present during the experiments. Occasionally, the presence of tintinnids extended the offered prey width spectrum down to ca $0.050 \mathrm{~mm}$. Herring larvae were sampled using a large diameter glass tube as a pipette. Care was taken to sample larvae randomly from the surface, subsurface, midwater and bottom. They were put into a small glass vessel, anaesthetised with $0.005 \%$ MS222 in seawater and transferred to microscope slides where the water was removed, except for a thin film around the larva. The whole procedure had to be completed within $5 \mathrm{~min}$ because the larvae were found to empty their gut within this period, and their gut contents would otherwise have been lost.

Investigations. Fig. 2 shows herring larvae and prey organisms and describes parameters used for assessment.

Parameters were measured on anaesthetised herring larvae and on zooplankton organisms immediately after fixation in $4 \%$ formaldehyde-seawater solution. Measurements of the larval standard length were carried out with a stereo microscope (magnification: 16).

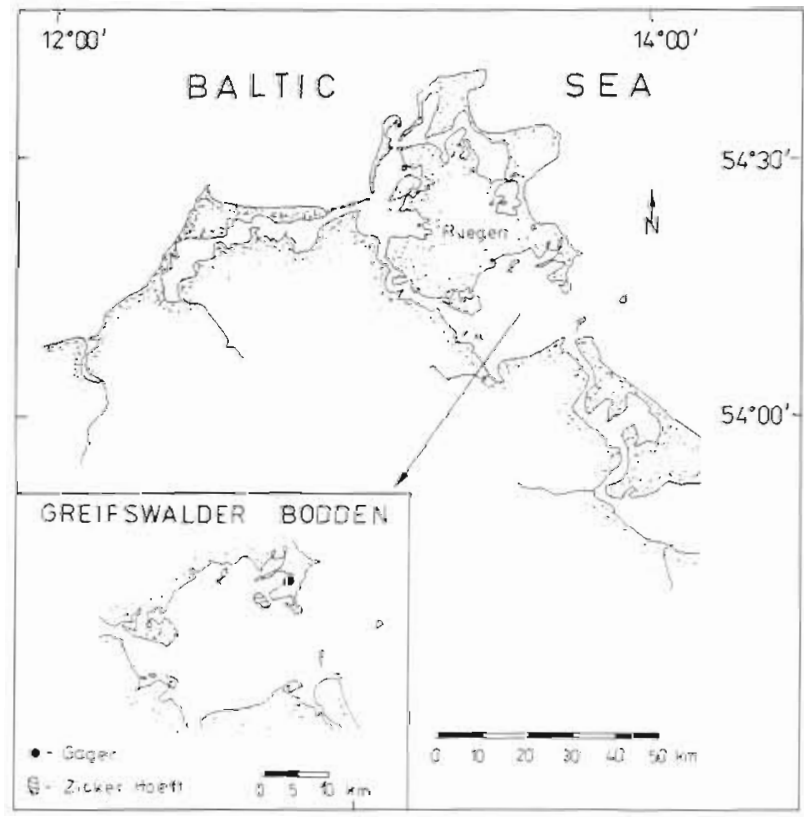

Fig. 1. Study area, Baltıc Sea coast, Germany. Herring eggs were collected at Zicker Hoeft, a main spawning location 
Table 1. Clupea harengus. Incubation and rearing conditions in the tanks in comparison with conditions in the sea. SD: standard deviation

\begin{tabular}{|c|c|c|c|c|c|c|}
\hline \multirow{3}{*}{$\begin{array}{l}\text { Year: } \\
\text { Larval cohort: } \\
\text { Date: }\end{array}$} & \multicolumn{3}{|c|}{1990} & \multirow{3}{*}{$\begin{array}{c}1991- \\
\text { 1st cohort } \\
8 \text { April-7 May }\end{array}$} & \multicolumn{2}{|c|}{1992} \\
\hline & 1st cohort & 2nd cohort & 3rd cohort & & 1st cohort & 2nd cohort \\
\hline & 1-28 April & 17 April -9 May & 29 April-11 May & & 3-18 April & 5-27 May \\
\hline \multicolumn{7}{|l|}{ Temperature $\left({ }^{\circ} \mathrm{C}\right) \pm \mathrm{SD}$} \\
\hline During egg incubation & $9.1 \pm 1.4$ & $7.7 \pm 1.6$ & $9.1 \pm 1.6$ & $6.9 \pm 2.4$ & $5.7 \pm 2.2$ & $10.7 \pm 0.0$ \\
\hline During larval rearing & $9.8 \pm 2.6$ & $13.3 \pm 4.4$ & $17.0 \pm 3.5$ & $8.8 \pm 1.8$ & $7.5 \pm 1.4$ & $13.4 \pm 2.4$ \\
\hline $\begin{array}{l}\text { During the early larval } \\
\text { period in the sed }\end{array}$ & $9.0 \pm 1.0$ & $11.1 \pm 3.1$ & $15.1 \pm 2.6$ & $8.8 \pm 1.6$ & $6.8 \pm 0.8$ & $15.0 \pm 3.4$ \\
\hline \multicolumn{7}{|l|}{ Salinity $\left(\%_{0}\right) \pm S D$} \\
\hline In the rearing tanks & \multirow{2}{*}{\multicolumn{3}{|c|}{$\begin{array}{l}9.8 \pm 0.2 \\
9.8 \pm 0.2\end{array}$}} & $7.2 \pm 0.1$ & \multicolumn{2}{|c|}{$7.8 \pm 0.2$} \\
\hline In the sea & & & & $7.2 \pm 0.1$ & \multicolumn{2}{|c|}{$7.8 \pm 0.2$} \\
\hline \multicolumn{7}{|c|}{ Oxygen saturation $(\%) \pm S D$} \\
\hline In the rearing tanks & & $58.7 \pm 10.5$ & & $83.2 \pm 3.3$ & \multirow{2}{*}{\multicolumn{2}{|c|}{$\begin{array}{c}93.2 \pm 9.0 \\
80 \pm 15\end{array}$}} \\
\hline In the sea & & $80 \pm 20$ & & $75 \pm 20$ & & \\
\hline
\end{tabular}

The other parameters were measured with a microscope on glass slides without coverslips and with a small amount of water (magnification: up to 320 for herring larvae; up to 400 for prey organisms; maximum magnification of the objectives: 20 for herring larvae; 40 for prey organisms).

Standard length $\left(L_{s}\right)$ was determined with an accuracy of $0.1 \mathrm{~mm}$. Yolk sac diameter $(h)$, mouth parameters, oesophagus diameter and prey width were measured with an accuracy of $0.001 \mathrm{~mm}$.

The mouth width is defined as the distance between the articulations of the jaws. The mouth opening is the distance between the foremost points of the upper and lower jaws at an opening angle of $45^{\circ}$ (see Shirota 1970, Dabrowski \& Bardega 1984). Mouth size measurements were carried out in 1990 only.

The mouth does not function until the upper and lower jaws have fully developed. Until this time, the mouth remains open, and cannot be used for feeding (see Flüchter 1962, Blaxter 1969, Klinkhardt 1984).

Minimum oesophagus diameter, hereafter referred to as oesophagus diameter or oesophagus opening,

Table 2. Clupea harengus. Prey organisms offered to herring larvae and their width

\begin{tabular}{|lc|}
\hline Prey organism & Width $(\mathrm{mm})$ \\
\hline Tintinnids & $0.048-0.055$ \\
Rotifers & $0.089-0.090$ \\
Gastropod larvae & $0.123-0.138$ \\
Bivalvia larvae & $0.138-0.172$ \\
Crustaceans: & \\
Acartia bifilosa & \\
$\quad$ Naupliar stages & \\
Copepodite stages & $0.062-0.129$ \\
\hline
\end{tabular}
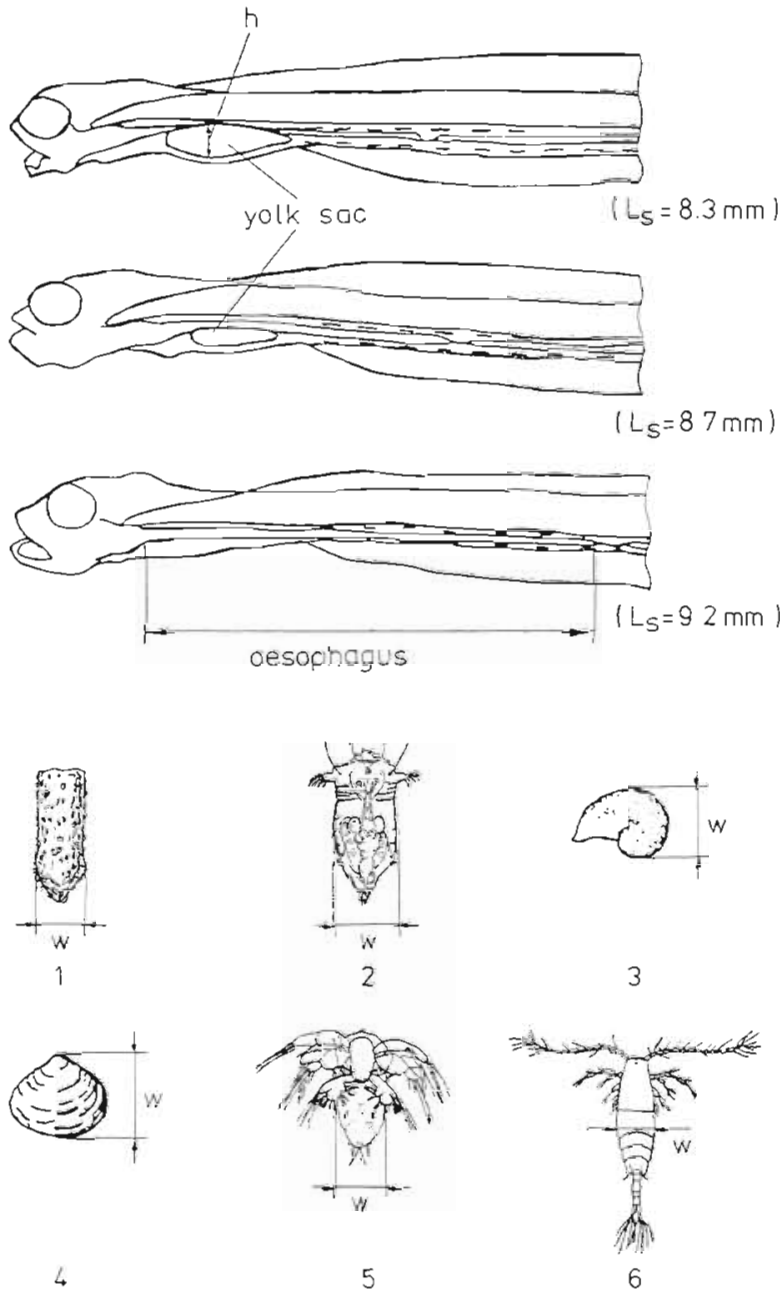

Fig. 2. Clupea harengus. Larvae and offered prey organisms. $L_{s}$ : standard length; $h$ : minor axis of yolk sac; $w$ : prey width for (1) tintinnid, (2) synchaete (rotifer), (3) snail larva, (4) bivalve larva, (5) naupliar stage, (6) copepodite stage 
was measured. During the yolk sac stage, the narrowest oesophagus diameter was recorded as being dorsal of the yolk sac. Oesophagus measurements took place in 1991 and 1992. The prey width $(w)$ was measured according to Fig. 2.

The transition to exogenous nutrition is thought to be complete when larvae have no more visible yolk reserves, and the incidence of feeding larvae reaches $100 \%$ (transition was complete within 3 wk of hatching). Only herring larvae containing food in the gut were considered for the investigation of the relation of mouth size and oesophagus diameter to the prey width.

\section{RESULTS}

\section{Larval mouth gape}

Mouth gape parameters $(\mathrm{mm})$ showed a positive correlation with standard length (mm) (Fig. 3): Mouth width $=0.047 L_{s}-0.076, \mathrm{r}^{2}=0.69, \mathrm{n}=170$, Mouth opening $=0.031 L_{s}-0.026, \mathrm{r}^{2}=0.66, \mathrm{n}=170$.
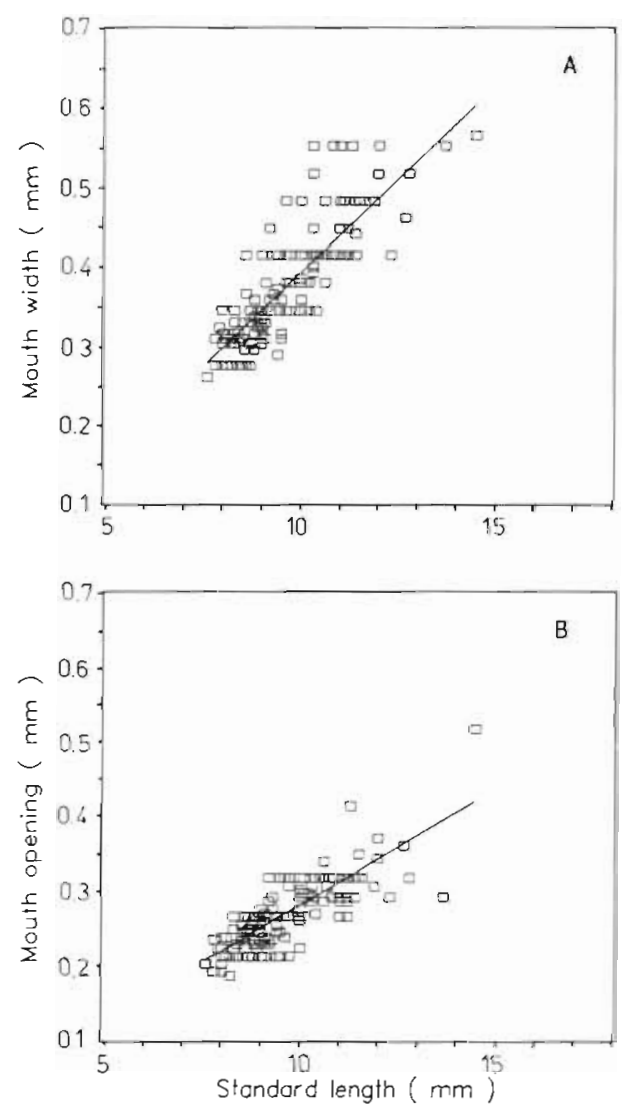

Fig. 3. Clupea harengus. (A) Mouth width and (B) mouth opening of larval hernng in relation to larval standard length. For formulae, see text. Mouth parameters were measured on 170 larvae
To enable comparisons with the oesophagus investigations, larvae smaller than $10.4 \mathrm{~mm}$ in length (mouth width $\leq 0.420 \mathrm{~mm}$; mouth opening $\leq 0.310 \mathrm{~mm}$ ) were considered first: in this case the width of prey organisms ingested by the herring larvae was not statistically different for larvae of different sizes (Fig. 4).

Taking into consideration all larval size groups (including larvae larger than $10.4 \mathrm{~mm}$ ), prey width tended to increase with increasing larval size.

The width of prey organisms used by the smallest herring larvae $\left(L_{s} \leq 8.3 \mathrm{~mm}_{\text {i }}\right.$ mouth width $=0.290$ to $0.296 \mathrm{~mm}$; mouth opening $=0.211$ to $0.232 \mathrm{~mm}$ ) was significantly lower than that of the largest $\left(L_{s} \geq\right.$ $12.4 \mathrm{~mm}_{\text {i }}$ mouth width $=0.550$ to $0.566 \mathrm{~mm}$; mouth opening $=0.360$ to $0.517 \mathrm{~mm}$ ). Prey width varied from 0.077 to $0.104 \mathrm{~mm}$ and from 0.106 to $0.170 \mathrm{~mm}$, corresponding to N2 to N4 of Acartia bifilosa and synchaetes (rotifers), and N5 to $\mathrm{C} 3$ of $A$. bifilosa, bivalves and snail larvae, respectively.

The ratio between mouth width or mouth opening and width of eaten prey was between 1.7 and 7.4 and between 1.4 and 5.7, respectively, based on all confidence intervals of the data set. No statistical differences were found for these ratios between the smallest $(\leq 8.3 \mathrm{~mm})$ and largest larvae $(\geq 12.4 \mathrm{~mm})$.

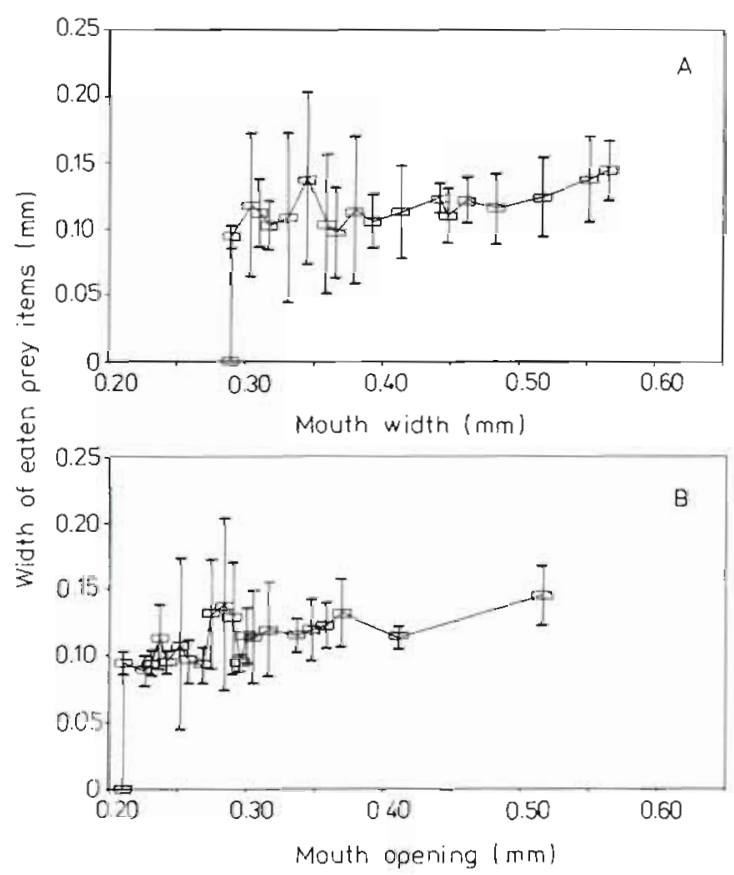

Fig. 4. Clupea harengus. Average width of prey eaten by herring larvae in relation to larval (A) mouth width and (B) mouth opening. Vertical bars are $95 \%$ confidence limits. 102 herring larvae were investigated; measured prey number per sample was mostly $>10$ and rarely $<10$ 


\section{Larval oesophagus diameter}

The oesophagus diameter increased biphasically during the early larval phase (Fig. 5). The first phase of oesophagus opening was rapid. Approximately $90 \%$ of the total observed increase occurred in this phase and corresponded to a decrease in the yolk sac diameter. The rapid phase occurred during Days 4 to 9 (1st cohort 1991); 7 to 9 (1st cohort 1992); and 3 to 6 (2nd cohort 1992). No attention was paid to the short period between Days 4 and 7 for the 1st cohort 1992, since the differences in oesophagus diameters were not significant in this period.

In the second phase, the oesophagus opening was much slower (Fig. 5) and was related to the increase in standard length (Fig. 6).

When considered with the results of other studies (see 'Discussion'), the present results and light microscopical investigations imply that the oesophagus diameter is influenced by yolk sac pressure during the first period (see Fig. 2). The value of $h$ was used as the criterion for yolk sac pressure because it is orientated on the same plane as the oesophagus diameter.

A mean decrease of $2.0 \pm 0.6 \mu \mathrm{m}$ in $h$ implies a $1.0 \mu \mathrm{m}$ increase in the oesophagus diameter, according to the first phase of the oesophagus opening (Fig. 5).

Prey width did not vary with oesophagus diameter for larvae of less than $10.4 \mathrm{~mm}$ length (Fig. 7). Larger larvae were not measured. The width of the consumed prey lay above the 1:1 line for larvae smaller than $9.3 \mathrm{~mm}$, and below for those larger than $9.3 \mathrm{~mm}$ in length. The ratio between the minimum oesophagus diameter and the width of the eaten prey was between 0.5 and 1.4 , when taking into account all confidence intervals of the data set.

\section{Time of first external feeding}

Different events in herring larva development are summarized in Table 3. The first feeding time is defined as that time point when any herring larvae were observed to have prey in their gut. The feeding incidence was 2 to $3 \%$ and 25 to $40 \%$ respectively for larvae of early (1st) and late ( 2 nd and $3 r d$ ) cohorts at this time point. Since herring larvae of early spawnings had already reached the standard length measured at first feeding prior to the first feeding time, this time was also given in Table 3 .

Note that the first feeding for all herring larvae cohorts took place during or at the end of the period when the oesophagus had just opened due to reduction in yolk sac pressure. However, the first feeding time did not coincide with events such as the begin-

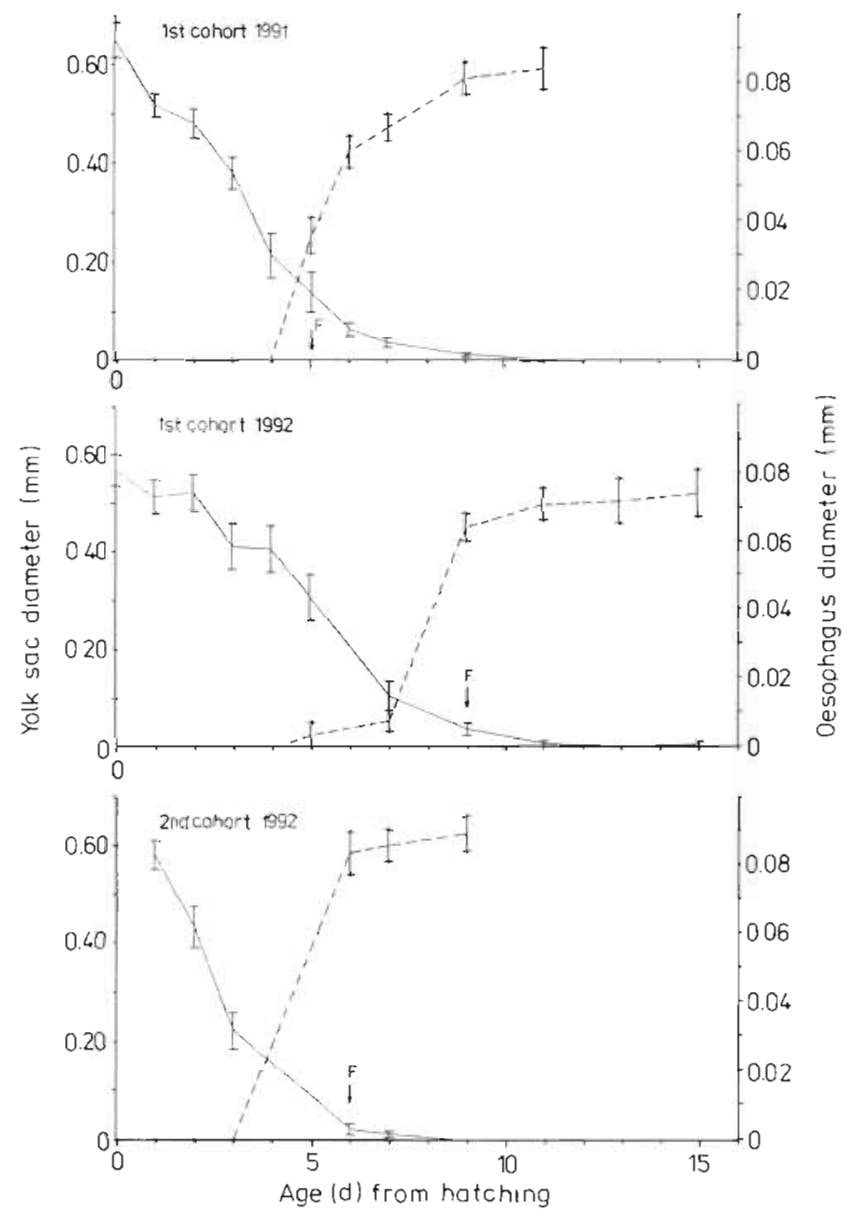

Fig. 5. Clupea harengus. Decrease of yolk sac diameter (solid line) and increase of oesophagus opening (broken line) for different herring larvae cohorts during early larval life. Vertical bars are $95 \%$ confidence limits; F: first feeding. At least 30 larvae per sample were measured for yolk sac diameter The number of oesophagus measurements amounted to mostly $>30$ per sample and rarely 10 to 30 per sample

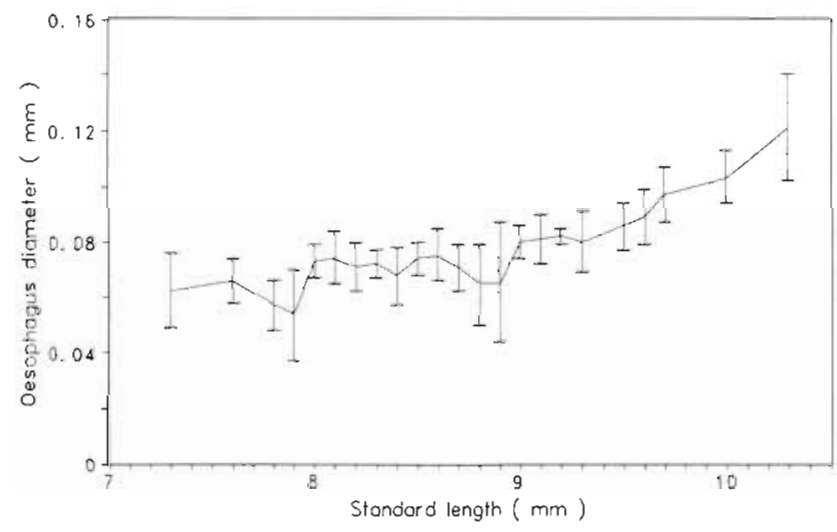

Fig. 6. Clupea harengus. Oesophagus diameter of larval herring in relation to larval standard length. Vertical bars are $95 \%$ confidence limits. 314 larvae, with at least 5 individuals per sample, were measured 


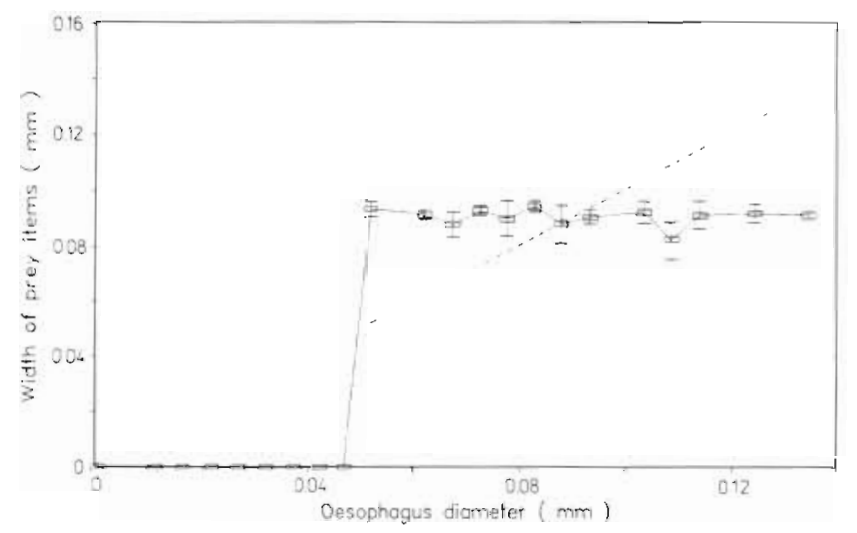

Fig 7 Clupea harengus. Average width of prey eaten by herring larvae in relation to larval oesophagus opening. Broken line represents the 1:1 line where prey width = oesophagus diameter. Vertical bars are $95 \%$ confidence limits. Gut content was analysed in 324 larvae, prey number per sample was mostly $>30$ and rarely between 10 and 30

ning of mouth function, or the time when the feeding standard length was first reached. This is particularly noticeable for larvae of early (1st) cohorts.

At the first feeding, larvae with gut contents $(n=14)$ had a standard length of between 8.1 and $8.7 \mathrm{~mm}$, values for the mean mouth width and opening of 0.305 to $0.333 \mathrm{~mm}$ and 0.225 to $0.244 \mathrm{~mm}$, respectively, and a minimum oesophagus opering of 0.052 to $0.104 \mathrm{~mm}$. The consumed prey was 0.077 to $0.104 \mathrm{~mm}$ in width and consisted mainly of Acartia bifilosa N2 to N4 and synchaetes. The ratios (based on all confidence limits of the data set) between the mouth width or the mouth opening and the prey width were between 2.9 and 4.3 and between 2.2 and 3.2 , respectively. The ratio between the minimum oesophagus opening and the prey width varied between 0.5 and 1.4

\section{DISCUSSION}

Internationally accepted concepts maintain that larval fish survival, and hence, recruitment are primarily determined by the limitation of food, especially during the early larval life - during the transition from yolk nutrition to external feeding (see e.g. Hjort 1914 , Fraser 1970, Cushing 1975). Furthermore, larvae must be able and ready to use external food. Thus, the question arises, which larval parameters determine the feeding start and the size of food organisms eaten? Earlier and recent studies restricted their investigations to certain parameters, such as fish length and mouth width, as prerequisites for an effective swirnming and prey catching modus, and to the development of the nervous system, sense organs, gill apparatus and gut.

The present study shows that larvae of the 2 nd and 3 rd cohorts started external feeding as soon as all parameters mentioned (standard length at the first feeding time, mouth function, gut function) were developed (Table 3). However, in contrast, larvae of the 1st cohorts did not begin feeding, although all parameters mentioned were developed: the standard length, which was measured at the start of feeding, had already been attained 2 to $3 \mathrm{~d}$ prior to the first feeding; mouth and gut functioned 2 to $3 \mathrm{~d}$ and 1.5 to $6.5 \mathrm{~d}$ prior to the first feeding, respectively. Thus, on this evidence, the beginning of external feeding activities must be determined by other factors. First feeding took place during or at the end of the period when the oesophagus had significantly opened for all herring larvae cohorts. During this period, the increase of the oesophagus diameter is related to the decrease of the yolk sac diameter $(h)$, rather than to the increase in standard length. The oesophagus opening process has not previously been investigated in detail. Whereas the

Table 3. Clupea harengus. Timing of events during the early larval phase with larvae of different cohorts in 1990,1991 and 1992 F: first feeding

\begin{tabular}{|c|c|c|c|c|c|c|}
\hline \multirow[t]{2}{*}{ Year/cohort } & \multicolumn{6}{|c|}{ Days from fertilization to. } \\
\hline & Hatching & $\begin{array}{l}\text { Gut function } \\
\text { according to } \\
\text { Johnston (1993) }\end{array}$ & $\begin{array}{l}\text { Mouth } \\
\text { function }\end{array}$ & $\begin{array}{l}\text { Age, when the } \\
\text { standard length measured } \\
\text { at } F \text { was first reached }\end{array}$ & $\begin{array}{l}\text { Age during the } \\
\text { phase of rapid } \\
\text { oesophagus opening }\end{array}$ & $\mathrm{F}$ \\
\hline \multicolumn{7}{|l|}{1990} \\
\hline 1st cohort & 19 & $22-23$ & 24 & 24 & no values & 27 \\
\hline 2nd cohort & 15 & 19 & $21-22$ & 20 & no values & 22 \\
\hline 3rd cohort & 12 & 16 & 16 & 16 & no values & 16 \\
\hline \multicolumn{7}{|l|}{1991} \\
\hline 1st cohort & 20 & $23-24$ & 23 & 23 & $24-29$ & 25 \\
\hline \multicolumn{7}{|l|}{1992} \\
\hline 1st cohort & 23 & $25-26$ & 30 & 30 & $28-32$ & 32 \\
\hline 2nd cohort & 12 & 16 & 18 & 18 & $15-18$ & 18 \\
\hline
\end{tabular}


opening of the oesophagus undoubtedly has physiological causes (e.g. Twongo \& MacCrimmon 1977, Bardonnet et al. 1993), it can be assumed from the results of the present study, from information in Govoni (1980) and in relation to some photographic evidence (Vieira \& Johnston 1992) that the increase of the oesophagus diameter is also due to mechanical factors such as the decrease of yolk sac pressure on the oesophagus owing to yolk resorption. In combination with yolk resorption, the increase of the oesophagus diameter could also be due to influences of the tissues around the yolk sac. However, no detailed investigations have yet been carried out concerning this latter question.

The results of this study further reveal that in general, the ratio between the oesophagus diameter and the width of eaten prey is closer to 1:1 than are the corresponding ratios for mouth sizes, although swallowing and oesophagus peristalsis occasionally enable a larger prey organism to be ingested.

Young naupliar stages of Acartia bifilosa and synchaetes were consumed from the beginning of the external feeding and for the following $15 \mathrm{~d}$. Only larvae older than $24 \mathrm{~d}\left(L_{s} \geq 12.4 \mathrm{~mm}\right)$, for which oesophagus measurements were not carried out, fed on significantly older naupliar and younger copepodite stages of Acartia bifilosa, as well as on mollusc veligers. The ratio between the oesophagus diameter and the width of the eaten prey was always between 0.5 and 1.4 . Few comparable results exist from investigations on other fish species, and no results have been published referring to oesophagus investigations on herring larvae. Economou (1991) found a ratio between oesophagus diameter and maximum prey width between 0.3 and 1 for 5 gadoid larvae, while Uotani (1985) calculated a ratio of between 0.7 and 1.2 for the same parameters for anchovy larvae. These values are comparable to those found in the present study.

With the condition that the yolk is utilized effectively in growth and that the morphological and functional stage necessary for the beginning of external feeding (see 'Introduction') has been achieved, it can be said that external feeding starts when the yolk is exhausted enough for the oesophagus to be opened widely enough for prey organisms to pass through it.

Thus, according to these results, external feeding can be prevented, especially for young larvae, not only by food limitation, but also by a restricted oesophagus opening - even if sufficient food is available. For that reason, the question of how much food is enough for the beginning of external feeding (see e.g. Beyer \& Laurence 1981, Kiørboe et al. 1985) needs reconsideration. Hence, clarification of whether the transition from yolk nutrition to external feeding is a critical period or not, attributed to food restriction, demands future investigations combining factors such as the ability and readiness of larvae to start external feeding and the feeding and survival of larvae at different food densities.

Acknowledgements. I sincerely thank Dr P. Spittler, Prof Dr U. Brenning and the colleagues of the working team for help and advice. I especially thank Dr R. Forster for reading, commenting and translating the manuscript and Anke Holst for drawing the figures. The main part of this work was supported by the BMFT (Bundesministerium für Forschung und Technologie), no. 03F0026A.

\section{LITERATURE CITED}

Aneer G, Florell G, Kautsk, U, Nellbring S, Sjöstedt L (1983) In situ observations of Baltic herring (Clupea harengus membras) spawning behaviour in the Asko-Landsort area, northern Baltic proper. Mar Biol 74:105-110

Bardonnet A. Gaudin P, Grolet O, Thorpe JE (1993) Presence of an oesophageal mucus plug at the time of emergence in grayling (Thymallus thymallus) and Atlantic salmon (Salmo salar). J Fish Biol 43:500-502

Batty RS (1987) Effect of light intensity on activity and foodsearching of larval herring, Clupea harengus: a laboratory study. Mar Biol 94:323-327

Beyer JE (1980) Feeding success of clupeoid fish larvae and stochastic thinking. Dana 1:65-91

Beyer JE, Laurence GC (1981) Aspects of stochasticity in modelling growth and survival of clupeoid fish larvae Rapp Pv Reun Cons int Explor Mer 178:17-23

Blaxter JHS (1965) The feeding of herring larvae and their ecology in relation to feeding. Calıf coop ocean Fish Invest Rep 10:79-88

Blaxter JHS (1968) Rearing herring larvae to metamorphosis and beyond. J mar biol Ass U K 48:17-28

Blaxter JHS (1969) Development: eggs and larvae. In: Hoar WS, Randall DJ (eds) Fish physılogy III. Academic Press, New York, p 177-252

Blaxter JHS, Hunter JR (1982) The biology of the clupeoid fishes. In: Blaxter JHS, Russell FS, Yonge $M$ (eds) Advances in marine biology, Vol 20. Academic Press, London, p 1-223

Bremigan MT, Stein R A (1994) Gape-dependent larval foraging and zooplankton size: implications for fish recruitment. across systems. Can J Fish Aquat Sci 51:913-922

Busch A (1993) Nahrungsökologische Untersuchungen an den Larven des Rügenschen Frühahrsherings (Clupea harengus L.) im Greifswalder Bodden in den Jahren 1990 bis 1992. PhD thesis, Rostock University

Cohen RE, Lough RC (1983) Prey field of larval herring Clupea harengus on a continental shelf spawning area. Mar Ecol Prog Ser 10:211-222

Collins LA, Nelson SG (1993) Effects of temperature on oxygen consumption, growth, and development of embryos and yolk-sac larvae of Siganus randalli (Pisces: Siganidae). Mar Biol 117:195-204

Crockford T, Johnston LA (1993) Developmental changes in the composition of myofibrillar proteins in the swimming muscles of Atlantic herring, Clupea harengus. Mar Biol $115: 15-22$

Cushing DH (1975) Marine ecology and fisheries. Cambridge Univ Press, Cambridge

Dabrowski K (1984) The feeding of fish larvae: present 'state of the art' and perspectives. Reprod Nutr Develop 24 $807-833$ 
Dabrowski K, Bardega R (1984) Mouth size and predicted food size preferences of larvae of three cyprinid fish species. Aquaculture 40:41-46

Economou AN (1991) Food and feeding ecology of five gadoid larvae in the northern North Sea. J Cons int Explor Mer 47:339-351

Flüchter J (1962) Funktionsanatomische Untersuchungen am Kieferapparat der Heringslarven. Kurze Mitt Inst FischBiol Univ Hamburg 12:1-12

Flüchter $J$ (1964) Eine besonders wirksame Aquarienfiltrierung und die Messung ihrer Leistungen. Helgoländer wiss Meeresunters 11:168-170

Fortier L, Harris RP (1989) Optimal foraging and densitydependent competition in marine fish larvae. Mar Ecol Prog Ser 51:19-33

Fraser JH (1970) The ecology of the ctenophore pleurobrachia pileus in Scottish waters. ICES J Cons 33:149-168

Gibson RN, Ezzi IA (1992) The relative profitability of particulate- and filter-feeding in the herring, Clupea harengus L. J Fish Biol 40:577-590

Govoni JJ (1980) Morphological, histological, and functional aspects of alimentary canal and associated organ development in larval Lejostomus xanthurus. Rev Can Biol 39: $69-80$

Grosse DJ, Hay DE (1988) Pacific herring, Clupea harengus pallasi, in the Northeast Pacific and Bering Sea. In: Wilimovsky NJ, Incze LS, Westrheim SJ (eds) Species synopses, life histories of selected fish and shellfish of the Northeast Pacific and Bering Sea. Washington University, Seattle, p 34-54

Heath M (1989) A modelling and field study of grazing by herring larvae. Rapp Pv Réun Cons int Explor Mer 191 $233-247$

Hjort $J$ (191.4) Fluctuations in the great fisheries of northern Europe. Rapp Pv Réun Cons int Explor Mer 20:1-228

Johnston IA (1993) Temperature influences muscle differentiation and the relative timing of organogenesis in herring (Clupea harenqus) larvae. Mar Biol 116:363-379

Kiørboe T, Munk P, Støttrup JG (1985) First feeding by larval herring Clupea harengus L. Dana 5:95-107

Klinkhardt $M$ (1984) Untersuchungen zur Embryonalphase des Laiches Rügenscher Frühjahrsheringe unter besonderer Berücksichtigung natürlicher Mortalitätsraten auf einem ausgewählten Laichplatz des Greifswalder Boddens. PhD thesis, Rostock University
Lasker R (1975) Field criteria for survival of anchovy larvae. The relation between inshore chlorophyll maximum layers and successful first feeding. Fish Bull US 73:453-462

Lasker $\mathrm{R}(1978)$ The relation between oceanographic conditions and larval anchovy food in the California Current: identification of factors contributing to recruitment failure Rapp Pv Réun Cons int Explor Mer 173:212-230

Munk P (1992) Foraging behaviour and prey size spectra of larval herring Clupea harengus. Mar Ecol Prog Ser 80: $149-158$

Pedersen BH, Nilssen EM. Hjelmeland K (1987) Variations in the content of trypsin and trypsinogen in larval herring (Clupea harengus) digesting copepod nauplii. Mar Biol 94:171-181

Rosenthal H (1969) Untersuchungen über das Beutefangverhalten bei Larven des Herings Clupea harengus. Mar Biol $3: 208-221$

Rosenthal H, Hempel G (1970) Experimental studies in feeding and food requirements of herring larvae (Clupea harengus L.). In: Steele JH (ed) Marine food chains. University of California Press, Berkeley, p 344-364

Schnack D (1972) Nahrungsökologische Untersuchungen an Heringslarven. Ber dt wiss Kommn Meeresforsch 22: $273-343$

Shepherd JG, Cushing DH (1980) A mechanism for density dependent survival of larval fish as the basic of a stockrecruitment relationship. ICES J Cons 39:160-167

Shirota A (1970) Studies on the mouth size of fish larvae. Bull Jap Soc Scient Fish 36:353-368

Twongo TK, MacCrimmon HR (1977) Histogenesis of the oropharyngeal and oesophageal mucosa as related to early feeding in rainbow trout, Salmo gairdneri Richardson. Can J Zool 55:116-128

Uotani I (1985) The relation between feeding mode and feeding habit of the anchovy larvae. Bull Jap Soc scient Fish 51:1057-1065

Vieira VLA, Johnston IA (1992) Influence of temperature on muscle-fibre development in larvae of the herring Clupea harengus. Mar Biol 11.2:333-341

Ware DM (1975) Relation between egg size, growth, and natural mortality of larval fish. J Fish Res Bd Can 32: $2503-2512$

Werner RG, Blaxter JHS (1980) Growth and survival of larval herring (Clupea harengus) in relation to prey density. Can J Fish Aquat Sci 37:1063-1069

Manuscript first received: February 21, 1995

Revised version accepted: July 13, 1995 